\title{
Preliminary Report on the Flora of Southern Hidaka, Hokkaido (Yezo). XVIII.
}

\author{
By
}

\section{Hiroshi Hara.}

Received December 5, 1936.

\section{Convolvulaceae.}

Calystegia R. Brown (nom. conserv.)

$466^{(1) *}$ Calystegia Soldanella Roemer et Schultes, Syst. Veg. IV, p. 184 (1819).

Syn. Convolvulus Soldanella Linnaeus, Sp. Pl. ed. 1, I, p. 159 (1753).

Calystegia Soldanella R. Brown ex Link, Enum. Pl. Berol. I, p. 201 (1821).-Matsumura, Ind. Pl. Jap. II-2, p. 516 (1912).--Nakai, Veg. Apoi p. 66 (1930).-Masamune, Fl. \& Geobot. Stud. Yakusima p. 382 (1934).

Nom. Jap. Hama-hirugao.

Hab. on sandy coasts at the foot of Mt. Apoi, ete. Fl. Jul.

Dist. Formosa, Liukiu, Kyushu, Shikoku, Honshu, Yezo, S. Kuriles, Korea, China, Manchuria, Europe, N. Africa, America and Australia.

R. Brown did not make the combination, Calystegia Soldanella, in Prodr. Fl. Nov. Holl. p. 483 (1810).

467(2)**Calystegia japonica Choisy in Zollinger, Syst. Verz. Ind. Archip. Jap. II, p. 130 \& 132 (1854); non Convolvulus japonica THunberg. Syn. Calystegia Sepium R. Br. var. japonica Makino in Bot. Mag. Tokyo IX, p. 312 (1895) excl. syn. Thunb.; XV, p. 94 (1901) excl. syn. Thunb.-Matsumura, Ind. Pl. Jap. II-2, p. 516 (1912).-HandelMazzetti, Symb. Sinic. VII, p. 811 (1936).

Calystegia Sepium var. japonica f. angustifolia NAKAI in Bot. Mag. Tokyo XXIII, p. 107 (1909).

Calystegia subvolubilis Don f. angustifolia Makino et Nemoto, Fl. Jap. ed. 2, p. 972 (1931).

Calystegia japonica var. elongata Liou et Ling in Contr. Lab. Bot. Acad. Peipg. I, p. 25, t. VI, f. 5 (1931); in Fl. Illust. N. Chine I, p. 27, t. IX, f. 3 (1931).

Calystegia japonica f. angustifolia Makino, in litt. 
***. major (Makino) Makino, in litt.

Syn. Calystegia Sepium var. japonica f. major Makino in Innma, Sômokudzusetsu ed. Makino, I, p. 289 (1907); in Bot. Mag. Tokyo XXI, p. 162 (1907).--Matsumura, l. e. (1912).

Calystegia subvolubilis Don f. major Makino et Nemoto, l.c. (1931). Calystegia japonica var. integrifolia Liou et Ling, l.c. p. 24, t. VI, f. 4 (1931); l.c. p. 27, pl. IX, f. 2 (1931).

Nom. Jap. O-hirugao.

Hab. at the foot of Mt. Apoi. Fl. Aug.

Dist. Honshu, Yezo, Korea, China and Manchuria.

\section{Cuscutaceae.}

Cuscuta L.

$468^{(1)}$ Cuscuta japonica Chorsy in Zollinger, Syst. Verz. Ind. Archip. Jap. II, p. 130 \& 134 (1854).-Matsumura, Ind. Pl. Jap. II-2, p. 517 (1912).

Nom. Jap. Nenashi-kadzura.

Hab. near Porosanushibetsu, Shoya, etc. Fl. Aug.-Sep.

Dist. Liukiu, Kyushu, Shikoku, Honshu, Yezo, Korea, China, IndoChina, Manchuria and Dahuria.

\section{1. . Polemoniaceae.}

$469^{(1)}$ *Polemonium cæruleum Linnaeus, Sp. Pl. ed. 1, I, p. 162 (1753).

*var. yezoense Miyabe et Kudo in Trans. Sapporo Nat. Hist. Soc. IV, p. 99 (1913) (ut subsp. vulgare Brand var. yczoense).-'TAtew., Veg. Apoi p. 107 (1928).-NakaI, Veg. Apoi p. 66 (1930).

Nom. Jap. Hana-shinobu, Yezo-no-hanashinobu.

Hab. in forests at the foot of Mt. Apoi, Nikanbetsu valley and on grassy slopes near C. Erimo. Fl. Jun.-Jul.

Dist. Kyushu, Honshu and Yezo.

Some specimens from the Cape Erimo approach to var. laxiflorum Miyabe et Kudo in having narrower small leaflets.

\section{Borraginaceae.}

Cynoglossum L.

470 (1) Cynoglossum asperrimum NAKAI in Bot. Mag. Tokyo XXXVII, p. 6 (1923).

var. yesoense NAKAI, l.c. p. 7 (1923).

Syn. Cynoglossum furcatum (non Wallicil) Matsumura, Ind. Pl. Jap. II--2, p. 523 (1912) pro parte. 
Nom. Jap. Yezo-rurisô, Yezo-oni-rurisô (Makino et Nemoto 1925). Fl. Jul.

Hab. in the upper part of Horoman R., Nikanbetsu R. and Saruru.

Dist. sp. Kyushu, Shikoku, Honshu, Yezo, S. Kuriles and S. Korea.

Eritrichium SCHRAD.

$471^{(2)}$ *Eritrichium nipponicum Makino in Bot. Mag. Tokyo XVII, p. 51 (1903).-Matsumura, Ind. Pl. Jap. II-2, p. 525 (1912).-Mirabe et Kudo in Trans. Sapporo Nat. Hist. Soc. VI, p. 6 (1915).-Miyabe et Miyake, Fl. Saghal. p. 334, pl. X, fig. 3-6 (1915).

Syn. Hackelia nipponica Brand in Fedde, Rep. Sp. Nov. XXII, p. 104

(1925); in Engler, Pfl.-reich IV-252, Ht. 97, p. 135 (1931).

*f. albiflorum (KoIDzUmi) HARA, comb. nov.

Syn. Eritrichium nipponicum var. albiflorum KoIdzum in Bot. Mag. Tokyo XXX, p. 80 (1916).-Tatew., Veg. Apoi p. 108 (1928).

Eritrichium yesoense NakaI f. albiflorum NakaI, Veg. Apoi p. 66 (1930).

Nom. Jap. Shirobana-miyama-murasaki, Shirobana-yezoruri-murasaki (NAKAI 1930).

Hab. in gravelly places in the upper part of Mt. Apoi (rare) and Mt. Horoman (not uncommon).

*f. yesoense (NAKaI) Hara, f. nov.

Syn. Eritrichium nipponicum (non Makino) Tatew., Veg. Apoi p. 107 (1928).

Eritrichium yesoense NakaI, Veg. Apoi p. 66 (1930) nom. nud.

A typo in omnibus partibus densius canescenti-hirsutis, pilis rigidioribus, caulibus vulgo robustioribus differt.

Nom. Jap. Yezo-ruri-murasaki (NAKaI 1930).

Hab. in gravelly places in the upper part of Mt. Apoi, Mt. Pinneshiri and Mt. Moroman. Fl. Jul.-early Aug.

Dist. sp. Mid. Honshu, Yezo (prov. Hidaka and prov. Ishikari) and Saghalien.

This species is very closely related to $E$. pectinatum. DC. and belongs without doubt to Eritrichium. Specimens of Mt. Apoi are densely covered with more rigid hairs than those of Honshu. But specimens of Mt. Yubari show intermediate characters, and those from Chikahoro in Saghalien agree well with Honshu specimens. In Mt. Horoman light blue-flowered form prevails and in Mt. Apoi I found an individual with lilac flowers.

Lithospermum L.

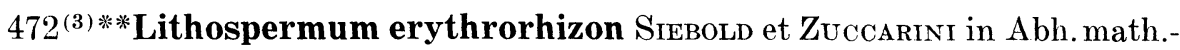


phys. Kl. Akad. Wiss. Muenchen IV-3, p. 149 (1846).

Syn. Lythospermum murasaki Siebold, Syn. Pl. Oecon. Jap. p. 32 (1830), nom. seminud.

Lithospermum officinale L. var. japonica MiqueL in Ann. Mus. Bot. Lugd.-Bat. II, p. 94 (1865).

Lithospermum officinale $\beta$. erythrorhizon Maximowicz in Bull. Acad. Imp. Sci. St.-Pétersb. XVII, p. 441 (1872).-Matsumura, Ind. Pl. Jap. II-2, p. 525 (1912).

Lithospermum officinale subsp. erythrorrhizon HandeL-MazzetTi, Symb. Sin. VII-4, p. 817 (1936).

Nom. Jap. Murasaki.

Hab. at the foot of Mt. Apoi. Fl. July-early Aug.

Dist. Kyushu, Shikoku, Honshu, Yezo, Korea, China, Manchuria, Ussuri, Amur and Mongolia.

Mertensia RoTir. (nom. conserv.)

473(4)* Mertensia maritima S. F. Gray, Nat. Arr. Brit. Pl. p. 354 (1821). Syn. Pulmonaria maritima Linnaeus, Sp. Pl. ed. 1, I, p. 136 (1753).

Pneumaria maritima HiLı, Veg. Syst. VII, p. 40, pl. 37, fig. 3 (1764).

Mertensia maritima LiNk, Handb. Erkenn. nutz. häuf. vork. Gewäch.

I, p. 58 (1829).-G. Don, Gen. Syst. IV, p. 320 (1838).

*subsp. asiatica T'AKEDA in Journ. Bot. XLIX, p. 222 (1911).-Kudo, Fl. Param. p. 152 (1922).-Hultén, Fl. Kamt. IV, p. 85 (1930).-Komarov, Fl. Penin. Kamt. III, p. 52 (1930).

Syn. Mertensia maritima (non G. Don) quoad pl. Jap.-Matsumura, Ind. Pl. Jap. II-2, p. 526 (1912).

Mertensia asiatica MacBride in Contr. Gray Herb. new ser. XLVIII, p. 53 (1916).-NAKaI in Bot. Mag. Tokyo XXXVIII, p. [154] (1924); Veg. Apoi p. 66 (1930).

Nom. Jap. Hama-benkeisô.

Hab. on sandy coasts at the foot of Mt. Apoi, between Shoya and Saruru, etc. Fl. Jul.-Aug.

Dist. N. Honshu, Yezo, Kuriles, Saghalien, Korea, Ussuri, Ochotsk and Kamtchatka.

Specimens from the Aleutian Is. (Atka), Anadyr and Anastasia belong to the head form and those from the Bering Is. have intermediate characters as Dr. Hultín had pointed out.

\section{Myosotis L.}

$474^{(5) *}$ Myosotis sylvatica Hoffmann, Deuts. Fl. I, p. 61 (1791); ed 2, p. 85 (1800).-Kudo, Rep. Veg. N. Saghal. p. 207 (1924).-Komarov, Fl. 
Penin. Kamt. III, p. 49 (1930).-HARA in Journ. Jap. Bot. XII, p. 164 (1936).

Syn. Myosotis intermedia (non Link) Makino in Bot. Mag. Tokyo XVII, p. 53 (1903).-Matsumura, Ind. Pl. Jap. II-2, p. 526 (1912).-Nakai, Veg. Apoi p. 66 (1930).

Myosotis alpestris F. W. Schmidt subsp. asiatica Vestergrex apud Hultén, Fl. Kamt. IV, p. 80 (1930).

Nom. Jap. Yezo-murasaki (Makino 1903), Miyama-wasurenasô (MiyaBE: et Mryake 1915).

Hab. in the lower part of Mt. Apoi, Samani, ete. Fl. late Mayearly Jun.

Dist. Mid. \& N. Honshu, Yezo, S. Kuriles, Saghalien, Korea, China, Manchuria, Amur, Mongolia, Dahuria, Kamtchatka, Siberia, Altai, Himalaya, Caucasus, Asia Minor, Europe and N. $\Lambda$ frica.

\section{Verbenaceae.}

Callicarpa L.

$475^{(1) *}$ Callicarpa japonica Tiluniberg, Fl. Jap. p. 60 (1784).-Ma'tsunura, Ind. Pl. Jap. II-2, p. 529 (1912).-NAKAI, Trees \& Shrubs Jap. ed. 1, I, p. 334, f. 182 (1922) ; ed. rev., I, p. 452, f. 214 (1927) ; Fl. Sylv. Korea. XIV, p. 30, tab. 6 (1923); Veg. Apoi p. 67 (1930).-Moldenke in Fedde, Rep. Sp. Nov. XL, p. 87 (1936).

Nom. Jap. Murasali-shikibu.

Hab. in the lower part of Mt. Apoi. Fl. late Jul.

Dist. Formosa, Liukiu, Kyushu, Shikoku, Honshu, Yezo, Korea, Man(huria and China.

Caryopteris Bunge.

$476^{(2)} *$ Caryopteris divaricata Maximowicz in Bull. Acad. Imp. Sci. St.Pétersb. XXIII, p. 390 in adnota (1877).-NakaI, Fl. Korea. II, p. 137 (1911).-Matsumura, Ind. Pl. Jap. II-2, p. 530 (1912).-Tatew., Veg. Apoi p. 108 (1928).-Nakai, Veg. Apoi p. 67 (1930).

Syn. Clerodendron divaricatum Siebold et Zuccarini in Abh. math.-phys.

Kl. Akad. Wiss. Muenchen IV-3, p. 154 (1846).

Nom. Jap. Kariganesô.

Hab. in the lower part of Mt. Apoi, Mt. Horoman, etc.

Dist. Kyushu, Honshu, Yezo, Korea and China.

Clerodendron L.

$477^{(3)} *$ Clerodendron trichotomum Tinunberg in Nova Acta Reg. Soc. Sci. 
Upsal. III, p. 208 (1780) ; Fl. Jap. p. 256 (1784).-Matsumura, Ind. Pl. Jap. II-2, p. 532 (1912).-NakaI, Trees \& Shrubs Jap. ed. rev., I, p. 468, f. 221 (1927).--Tatew., Veg. Apoi p. 108 (1928).-Nakai, Veg. Apoi p. 67 (1930). Syn. Siphonanthus trichotomus NAKaI in Bot. Mag. Tokyo XXXVI, p. 24 (1922); Trees \& Shrubs Jap. ed. 1, I, p. 345, f. 188 (1922); Fl. Sylv. Korea. XIV, p. 35, tab. 10 (1923).

Nom. Jap. Kusagi.

Hab. at the foot of Mt. Apoi, etc. Fl. Aug.

Dist. Formosa, Liukiu, Kyushu, Shikoku, Honshu, Yezo, Korea, Manchuria and China.

\section{Labiatae.}

Agastache Clayton.

$478^{(1)}$ * Agastache rugosa O. Kuntze, Rev. Gen. Pl. II, p. 511 (1891).Kudo, Enum. Labiat. Kuril. et Yezo in Journ. Coll. Sci. Imp. Univ. Tokyo XLIII-8, p. 16 (1921); Labiat. Sino-Jap. Prodr. in Memoir. Fac. Sci. \& Agr. Taihoku Imp. Univ. II-2, p. 220 (1929).-NAKAI, Veg. $\Lambda$ poi p. 67 (1930).

Syn. Lophanthus rugosus Fischer et Meyer in Ind. Sem. Hort. Petrop. I, p. 31. (1835); in Linnaea X, Litt.-Ber. p. 94 (1836).-Matsumura, Ind. Pl. Jap. II-2, p. 542 (1912).-Komarov et Klob.-Alisova, Key Pl. Far East. Reg. USSR. II, p. 899, tab. 272 (1932).

*f. hypoleuca (KUDo) HARA, comb. nov.

Syn. Agastache rugosa var. hypolenca Kudo, l.e. (1921).--Tatew., Veg. Apoi p. 108 (1928).

Nom. Jap. Kita-kawamidori (Kudo 1921).

Hab. at the foot of Mt. Apoi, Shoya, etc. Fl. mid. Aug.--early Sep.

Dist. sp. Formosa, Kyushu, Honshu, Yezo, Korea, China and Manchuria.

The specimens of our district are densely pubescent on the undersurface of leaves and belong to f. hypoleuca which, however, passes gradually to the typical form.

Ajuga L.

$479^{(2)} *$ Ajuga ciliata Bunge in Mém. Sav. Étrang. Acad. Sei. St.-Pétersb. IT, p. 125 (1833).

*\%f. Chaneti Kudo, Enum. Labiat. Kuril. et Yezo p. 4 (1921); Iabiat. Sino-Jap. Prodr. p. 285 (1929).

Syn. Ajuga Chaneti Léveillé et Vaniot ex Léveillé in Fedde, Rep. Sp. Nov. VIII, p. 258 (1910). 
Nom. Jap. Kai-jindô.

Hab. at the foot of Mt. Apoi, Mt. Ruchishi, Shoya, etc. Fl. late Jun.-Jul.

Dist. Kyushu, Honshu, Yezo and China.

480(3)*Ajuga yesoensis Maximowicz ex Franchet et Savatier, Enum. Pl. Jap. II, p. 467 (1876).-Kudo, Enum. Labiat. Kuril. et Yezo p. 3 (1921) (f. typica Kudo); Labiat. Sino-Jap. Prodr. p. 279 (1929).-Tatew., Veg. Apoi p. 108 (1928) (f. typica).

Nom. Jap. Nishiki-goromo.

Hab. at the foot of Mt. Apoi, Shoya, Saruru-sanclô, etc. Fl. late May -Aug.

Dist. Shikoku, Honshu and Yezo.

Amethystanthus NAKAI.

481 (4)**Amethystanthus inflexus NaKaI in Bot. Mag. Tokyo XLVII I, p. 786 (1934).

Syn. Ocymum inflexum Thunberg, Fl. Jap. p. 249 (1784).

Plectranthus inflexus Vaml ex Bentham, Labiat. Gen. et Sp. p. 711 (1832-36).-Kudo, Enum. Labiat. Kuril. et Yezo p. 53 (1921).

Isodon inflexus Kudo, Labiat. Sino-Jap. Prodr. p. 127 (1929).--MAsAMune, Fl. \& Geobot. Stud. Yakusima p. 393 (1934).

Nom. Jap. Yama-hakka.

Hab. at the foot of Mt. Apoi, Saruru, ete. Fl. Aug.

*var. macrophyllus NAKAI, l.c. p. 787 (1934).

Syn. Plectranthus inflexus $\gamma$. macrophyllus Maximowicz in Bull. Acad.

Imp. Sci. St.-Pétersb. XX, p. 453 (1875).--NakaI, Veg. Apoi p. 67 (1930).

Plectranthus inflexus f. macrophyllus Kudo, l.c. p. 54 (1921).-TATEw., Veg. Apoi p. 109 (1928).

Isodon inflexus var. macrophyllus Kudo, l.c. p. 128 (1929).

Nom. Jap. Ôba-yamahakka.

Hab. at the foot of Mt. Apoi, Shoya, etc. Fl. Aug.--Sep.

Dist. sp. Kyushu, Shikoku, Honshu, Yezo, Korea, Manchuria and China.

Chelonopsis Miquel.

482(5)*Chelonopsis subglabra KoIdzumi, Fl. Symb. Or.-Asia. p. 15 (1930). Syn. Chelonopsis moschata Miq. $\beta$. subglabra Miquel in Ann. Mus. Bot. Lugd.-Bat. II, p. 111 (1865).

*var. jesoensis (KoIDzumi) HARA, comb. nov. 
Syn. Chelonopsis moschata (non Miqueu) Kudo, Enum. Labiat. Kuril. et Yezo p. 24 (1921); Medic. Pl. Hokkaido tab. 81 (1922); Labiat. Sino-Jap. Prodr. p. 151 (1929) pro parte.-Tatew., Veg. Apoi p. 108 (1928).-Nakar, Veg. Apoi p. 67 (1930).

Chelonopsis Yagiharana Hisauchi et Matsuno var. jesoensis KoIDZUMI, l.c. p. 16 (1930).

Nom. Jap. Yezo-jakôsô.

Hab. in the lower part of Mt. Apoi, Samani, Saruru-sandô, ete. Fl. Aug.

Dist. N. Honshu and Yezo. sp. Shikoku and Honshu.

The specimens of Yezo have usually broader leaves than those of Honshu and Shikoku, but the hairiness on calyces and leaves varies considerably also in the plant of Honshu. C. Yagiharana which is limited in the middle part of Honshu has smaller and shorter leaves than C. subglabra, and the hairs on calyces and pedicels are patent and never curved as in the latter.

\section{Clinopodium L.}

$483^{(6) *}$ Clinopodium chinense O. Kuntze, Rev. Gen. Pl. II, p. 515 (1891)

*subsp. grandiflorum (Maximowicz) Hara in Journ. Jap. Bot. XII, p. 39 (1936).

*var. parviflorum HARA, l.c. p. 41, fig. 29 (1936).

Syn. Satureia chinensis (non Briquet) Kudo, Enum. Labiat. Kuril. et Yezo p. 37 (1921) ; Labiat. Sino-Jap. Prodr. p. 102 (1929).-NAKaI, Veg. Apoi p. 67 (1930).

Satureia chinensis $\alpha$. parviflora Kudo, l.c. p. 38, t. II, fig. 25 a-c (1921) pro major. part.

Satureia chinensis $\beta$. megalantha Kudo, l.c. p. 39, t. II, fig. 25 d-f (1921) excl. syn.

Calamintha polycephala (non Vaniot) Handel-Mazzettr in Acta Hort. Gotob. IX, p. 84 (1934) pro parte.

Nom. Jap. Kurumabana, Oku-kurumabana (Kudo).

Hab. at the foot of Mt. Apoi, ete. Fl. Jul.-Aug.

Dist. Kyushu, Shikoku, Honshu, Yezo, S. Kuriles and Korea.

***var. shibetchense Kordzumi in Bot. Mag. Tokyo XLIII, p. 387 (1929).--HARA, l.c. p. 43 (1936).

Syn. Calamintha umbrosa Benth. var. shibetchensis Léveillé in Fedde, Rep. Sp. Nov. IX, p. 322 (1911).

Nom. Jap. Yezo-kurumabana (KoIDzumi), Yama-kurumabana.

Hab. in shady places at the foot of. Mt. Apoi, Mt. Ruchishi, etc. Fl. Jul.

Dist. Kyushu, Honshu, Yezo and Korea.

(To be continued.) 